null • TCC Africa webcasts

\title{
Uganda_National launch and access to Dimensions
}

\section{Joy Owango}

Published on: Aug 28, 2021

License: Creative Commons Attribution 4.0 International License (CC-BY 4.0). 
Recording:

More about CUUL

The Consortium of Uganda University Libraries (CUUL) facilitates effective and efficient collaboration and resource sharing among university and institutional libraries in Uganda in order to strengthen the library services provided to the students, staff and other patronage of the institutions: https://cuul.or.ug/ 